\title{
Water Quality Analysis Relation To Phytoplankton Community And Fish Resources in Teluk Gelam Lake, Ogan Komering Ilir
}

\author{
Septika Putri Anggraini ${ }^{1}$, Suheryanto ${ }^{2}$, Herpandi $^{3}$ \\ ${ }^{I}$ Students at Enviromental Management, Postgradute Program Sriwijaya University \\ ${ }^{2}$ Lecturers at Department of MIPA, Sriwijaya university \\ ${ }^{3}$ Lecturers Faculty of Agriculture, Sriwijaya University, Inderalaya. \\ *Corresponding Author: suheryanto_mhg254@mipa.unsri.ac.id
}

Article history

\begin{tabular}{cccc} 
Received & Received in revised form & Accepted & Available online \\
24 June 2021 & 01 August 2021 & 28 December 2021 & 31 December 2021 \\
\hline
\end{tabular}

\begin{abstract}
This study aimed to analyze the quality of the waters and its relationship with the structure of phytoplankton communities and fish resources. This research was conducted in March 2021 at lake Teluk Gelam Ogan Komering Ilir. Phytoplankton sampling has been done once with 3 replays and there are 5 station points. Measurement of water quality parameters physical and chemical waters include temperature, $\mathrm{pH}$, dissolved oxygen (DO), ammonia, brightness, turbidity, depth, nitrite, nitrate, and phosphate. Water quality analysis was calculated using the pollution index method (IP) and evaluated based on environmental quality standards according to the Decree of the State Minister for the Environment Number 115 of 2003. Based on the results of research that have been conducted in the lake Teluk Gelam district Ogan Komering Ilir that the overall average parameters of water quality in the lake were still an adequate condition for the life of organisms, especially phytoplankton. And based on the observations on the composition of phytoplankton structures in the waters of the lake Teluk Gelam found 3 classes of phytoplankton consisting of Bacillariophyceae, Chlorophyceae, and Cyanophyceae with a varied number of genera, while the fertility level of Teluk Gelam lake waters is included in the eutrophic category.

Keywords: phytoplankton, Teluk Gelam lake and water quality
\end{abstract}

\section{Introduction}

Lake is lentic water of freshwater ecosystems, influenced by hydrological, chemical, and biological to support aquatic organisms living. There are two components in the aquatic ecosystem, namely biotic and abiotic. The biotic component consists of two, i.e., flora and fauna, including the aquatic organism (fish and phytoplankton). In contrast, abiotic components include all hydrological, chemical, and physical elements, such as temperature, depth, $\mathrm{pH}$, DO, etc. The sustainability of small fish depends on the phytoplankton available. The biotas are not the only linkage to each other but also affect the dynamic of the physical-chemical of waters[1]

Lake Teluk Gelam is located in a swamp forest, that utilized for capture fishery. The lake waters has the function to provide nutrients for aquatic organisms. Phytoplankton has a role as the ecological paramaters that can describe the characteristics of the fertility of waters[2]. Phytoplankton is the nutrient especially for the necton group (fishes) which the fish life cycle is started from fish larvae suspends their life from natural feed[3].

Lake Teluk Gelam is one of the natural resources that can produce various types of fish that local fishing communities have long used as a source of life [4]. Currently, lake Teluk Gelam was Vol. 6 No. 3, 84-92 developed as a recreational destination with hostelry. Along with the increasing number of residents and development activities that do not pay attention to the balance and carrying capacity of the environment, the quality of the lake ecosystem environment is decreasing due to pollution and environmental damage. The organic waste produced from development and tourism activities around lake Teluk Gelam[5], are thrown away to the waters increasing the pollution. It means the decrease of the water conditions is due to the increased activities of communities. Wastes produced by various human activities need to be considered because they affect the physical, chemical, and biological water quality [6]. The study aimed to analyze the physical and chemical parameters of the waters and compare the types and abundance of phytoplankton and fish of lake Teluk Gelam.

\section{Material and Methods}

The research was conducted in March 2021, located in Teluk Gelam Lake, Mulyaguna Village, Tanjung Lubuk Subdistrict, Ogan Komering Ilir Regency. Determination of stations is carried out using a purposive survey method based on the representativeness of the location of the waters and the character of the utilization of aquatic and fishery

http://dx.doi.org/10.22135/sje.2021.6.3.84-92 
resources in the lake. The observation location is divided into five stations The observation location is divided into five stations (Figure 1.) with the characteristics of each station's location as follows:
Station I (Greenery Area), Station II (Residential area and community activities), Station III (Tourism Area), Station IV (Agricultural and Rice Fields Area), Station V (Central area of Teluk Gelam Lake).
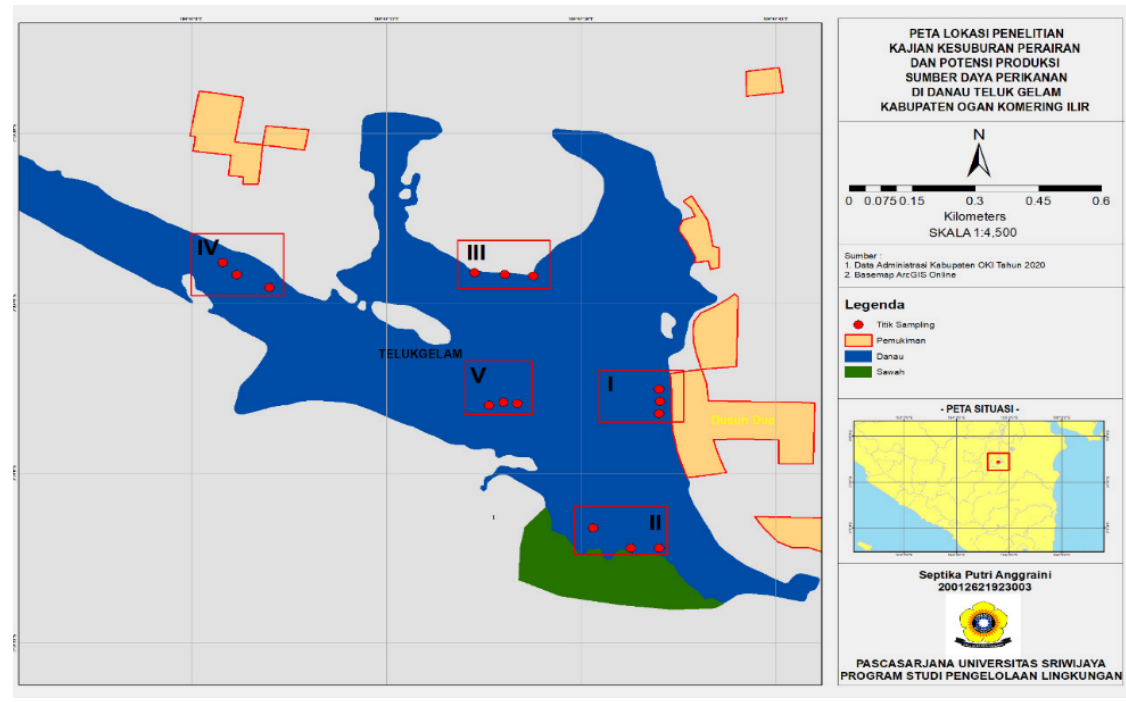

Figure 1. Research Sites

Data Collection. In this study, the primary and secondary data were collected. The primary data was collected for water quality measurement and interviewed the fishers, while secondary data was obtained from the previous studies and related institutions. Primary data collection was conducted in-situ (direct observation) and ex-situ (analysis in the chemical laboratory of the Palembang Institute for Industrial Research and Standardization and the biological laboratory of the Research Institute for Inland Fisheries and Extension). In-situ data collection was the temperature, depth, brightness, turbidity, DO (Dissolved Oxygen), $\mathrm{pH}$ parameters, while the ex-situ was the nitric, nitrite, ammonia, phosphate and plankton. The fishers were interviewed by using the questionnaires.
Water Sample Retrieval and Measurement. Water sampling stations are determined by using survey methods and by purposive sampling method that is to choose deliberately water sampling points. This study consists of 5 (five) water sampling stations where five stations have fishing activities or potential fishery resources. Determination of the location of the research based on (Figure 1). In each station is done 3 times replays, namely in the upstream and middle of the water, so that the total number of water sampling to be observed as much as 15 sampling. The sampling will be conducted in the morning at 09.00-14.00 WIB. The methods of measuring parameters of physics, chemistry, and aquatic biology used in this study are presented in Table 1.

Table 1 . The water quality parameters

\begin{tabular}{|c|c|c|c|c|}
\hline No & Parameters & Equipment & Method & Description \\
\hline \multirow[t]{4}{*}{ 1. Physics } & Temperature & Thermometer & SNI 06.6989.23-2005 & In situ \\
\hline & Brightness & Secchi disc & Wetzel dan Likens (1991) & In situ \\
\hline & Turbidity & Secchi disc & Wetzel dan Likens (1991) & In situ \\
\hline & Depth & Secchi disc & Wetzel dan Likens (1991) & In situ \\
\hline \multirow[t]{6}{*}{ 2. Chemical } & Dissolved Oxygen & DO meter & SNI 06.6989.14-2004 & In situ \\
\hline & $\mathrm{pH}$ & $\mathrm{pH}$ meter & SNI 06.6989.11-2004 & In situ \\
\hline & Nitrate & Spektrofotometer & SNI 06-2480.1991 & Ex-situ \\
\hline & Nitrite & Spektrofotometer & SNI 06-6989.9-2004 & Ex-situ \\
\hline & Ammonia & Spektrofotometer & SNI 06-6989.30-2005 & Ex-situ \\
\hline & Phosphate & Spektrofotometer & SNI 06-6989.31-2005 & Ex-situ \\
\hline 3. Biology & $\begin{array}{c}\text { The abundance of } \\
\text { phytoplankton }\end{array}$ & Plankton net & APHA 10200 B - 2012 & In situ \\
\hline
\end{tabular}




\subsection{Data Analysis.}

The abundance phytoplankton and water quality was calculated using the following formula with reference APHA (2005):

\subsubsection{Abundance Phytoplankton}

Where:

$$
\mathrm{N}=(\mathrm{Ns} \times \mathrm{Va}) \div(\mathrm{Vs} \times \mathrm{Vc})
$$

$\mathrm{N}$ : The total of individuals per liter example water, Ns: The totals of individuals plankton sedwick rafter, Va: The volume water in preparate sedwick rafter, $\mathrm{Vc}$ : The volume water filter example.

\subsubsection{Diversity Index}

The diversity of the species was calculated using the Shannon-Wiener Diversity Index (Shannon \& Wiener 1949), with the formula:

Where:

$$
\mathrm{H}^{\prime}=-\sum_{i=1}^{s} p i \ln p i
$$

$\mathrm{H}^{\prime}$ : Diversity of phytoplankton,

ni : the number of individuals species $i$,

$\mathrm{N}$ : the total of individuals per station.

\subsubsection{Equitability Indeks}

The equitability (evenness) index (E) (Odum $\&$ Barrett 2004) was calculated with the formula:

Where:

$$
E=\frac{H^{\prime}}{H \max }
$$

E : equitability index,

$\mathrm{H}^{\prime}$ : diversity index,

Hmax: - $\ln \mathrm{S}$,

$S$ : number of species found.

\subsubsection{Dominance Index}

The dominance index was calculated with the Simpson's index (Odum \& Barret 2004), with the formula:

$\mathrm{C}=\sum_{i=1,2,3, \ldots}^{S}\left(n i \frac{n i}{N}\right)_{2}$

Where:

$\mathrm{C}:$ dominance index,

ni: the number of individuals species

$\mathrm{i}, \mathrm{N}$ : the total of individuals per station.
2.1.5 Water Quality Analysis with Pollution Index Method

Data analysis techniques to determine the quality of the waters are carried out by pollution index method. This index is used to determine pollution levels relative to permitted water quality parameters. Based on the Decree of the Minister of Environment No. 115/2003.[7] The first step to calculating ip values is to compare the concentration of each tainted parameter (Ci) with the quality standard $(\mathrm{Li})$, so that the value $(\mathrm{Ci} / \mathrm{Li})$ of the measurement result for each parameter in question is obtained. Pollution index value is calculated by the following equation:

$$
P I j=\sqrt{\frac{\left(\frac{C i}{L i j}\right)_{M}^{2}+\left(\frac{C i}{L i j}\right)_{R}^{2}}{2}}
$$

Where:

Pij=pollution index for the designation of $j$;

$\mathrm{Ci}=$ concentration of water quality parameters $\mathrm{i}$;

$\mathrm{Lij}=$ concentration of water quality parameters i listed in the water designation standard $\mathrm{j}$;

$\mathrm{M}=$ maximum;

$\mathrm{R}=$ average.

The water quality assessment categories based on the pollution index value $(\mathrm{PIj})$ are as follows:

Table 2. Water quality classification from the US Environmental Protection Agency

\begin{tabular}{lll}
\hline Number & $\begin{array}{l}\text { The Pollution } \\
\text { Index Value }\end{array}$ & \multicolumn{1}{c}{ Category } \\
\hline 1 & $0 \leq \mathrm{PIj} \leq 1$ & $\begin{array}{l}\text { Meet the quality } \\
\text { standard }\end{array}$ \\
2 & $1<\mathrm{PIj} \leq 5$ & $\begin{array}{l}\text { Lightly polluted } \\
\text { Moderately polluted }\end{array}$ \\
3 & $5<\mathrm{PIj} \leq 10$ & $\begin{array}{l}\text { Heavily polluted } \\
4\end{array}$ \\
Note: source: Environmental Protection Agency (1975).
\end{tabular}

\subsubsection{Statistical Analysis.}

The relationship between water quality and phytoplankton community structure in lake Teluk Gelam was analyzed by using the main components of PCA (Principal Component Analysis). In contrast, the water quality was calculated by using the Pollution Index method. The index is used to determine pollution levels relative to water quality in lake Teluk Gelam ogan komering ilit.

\section{Results and Discussion}

The water quality of Teluk Gelam Lake was analysed and the results shown in Table 3. 
Table 3. Data the measurement of the avarage value water quality parameters in Teluk Gelam lake

\begin{tabular}{lcccccc}
\hline \multirow{2}{*}{ Parameters } & \multirow{2}{*}{ Unit } & \multicolumn{5}{c}{ Research Location } \\
\cline { 3 - 7 } & & Station I & Station II & Station III & Station IV & Station V \\
\hline Temperature & ${ }^{\circ} \mathrm{C}$ & 26,9 & 27,6 & 27,6 & 27,3 & 27,9 \\
Brightness & $\mathrm{M}$ & 1,10 & 1,50 & 1,67 & 1,23 & 1,27 \\
Turbidity & $\mathrm{Ntu}$ & 1,50 & 1,40 & 1,73 & 1,50 & 2,53 \\
Depth & $\mathrm{M}$ & 3,50 & 2,63 & 2,50 & 3,23 & 5,53 \\
DO & $\mathrm{mg} / \mathrm{L}^{1}$ & 0,39 & 2,66 & 2,40 & 1,63 & 1,60 \\
pH & - & 6,45 & 6,27 & 5,50 & 5,83 & 5,41 \\
Nitrate & $\mathrm{mg} / \mathrm{L}^{-1}$ & 0,002 & 0,01 & 0,01 & 0,001 & 0,001 \\
Nitrite & $\mathrm{mg} / \mathrm{L}^{-1}$ & 0,0 & 0,1 & 0,1 & 0,1 & 0,1 \\
Ammonia & $\mathrm{mg} / \mathrm{L}^{-1}$ & 0,005 & 0,007 & 0,006 & 0,005 & 0,006 \\
Phosphate & $\mathrm{mg} / \mathrm{L}^{-1}$ & 0,047 & 0,083 & 0,082 & 0,062 & 0,045 \\
\hline
\end{tabular}

\subsection{Water Quality Temperature}

Based on the data of the above parameters obtained temperature at each station is in the range of $26.9^{\circ} \mathrm{C}$ to $27.9^{\circ} \mathrm{C}$. Based on the standard quality of the waters that is $25-30{ }^{\circ} \mathrm{C}$ means that biota is still in a decent state to live in the waters of the bay lake. The optimum temperature for plankton growth ranges from $25{ }^{\circ} \mathrm{C}$ to $32{ }^{\circ} \mathrm{C}$. Thus, the water temperature conditions of the Teluk Gelam lake are still feasible for phytoplankton life. Temperature also affects the spread, composition as well as abundance of phytoplankton in the waters. According to the water temperature is one of the physical factors that affect the life of animals and aquatic plants one of which is plankton.

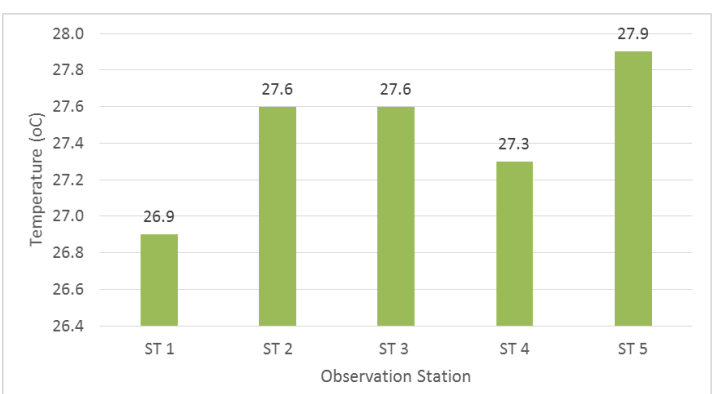

Figure 1. Temperature parameters in the waters of lake Teluk Gelam

\subsection{Brightness}

The results of the measurement of the brightness of the waters of Teluk Gelam lake in each station ranged from 1.10 to $1.67 \mathrm{~m}$, the lowest brightness value was found in station I and the highest brightness value was found in station III, from the data (figure 2.) the brightness was seen that there was a tendency to increase the brightness value in stations II and III because station II had settlements and human activity and station III there was a tourism area that caused high suspended particles and organic materials in the waters of the lake that comes from the mainland. But the brightness value in this study is still in accordance with the life of aquatic organisms, especially phytoplankton. The brightness value expressed in meters is strongly influenced by suspended particle materials, colloidal particles, turbidity, water color, relic bodies, detritus, plankton and weather conditions. A good brightness value for the survival of aquatic organisms is $>45 \mathrm{~cm}$ [8].

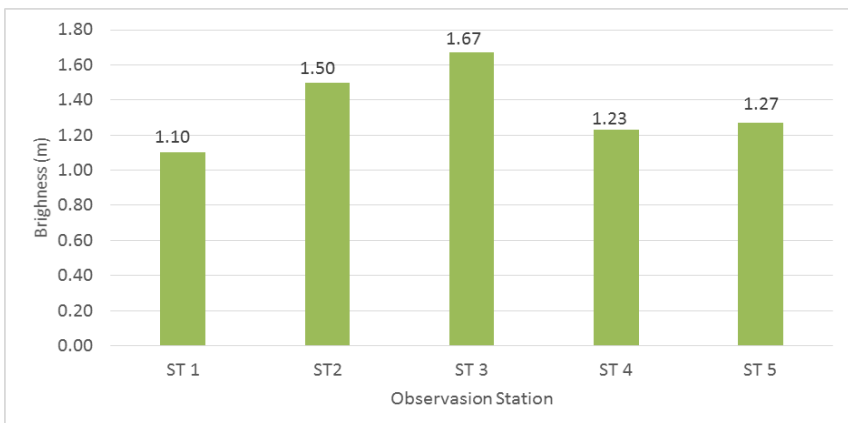

Figure 2. Brightness parameters in the waters of lake Teluk Gelam

\subsection{Turbidity}

The result of the measurement of turbidity in the waters of Teluk Gelam lake ranges from 1.502.53 NTU in Figure 3. The lowest turbidity value is found in station II which is a residential area that causes low turbidity value and the highest turbidity value is found in station $\mathrm{V}$ where the station is an area of the middle of Teluk Gelam lake[9]. Explains that turbidity results in the obstruction of light penetration needed for photosynthesis (phytoplankton). The higher the turbidity means the less sunlight that enters to the bottom of the water, resulting in the disruption of biota growth in the lake waters. The value of turbidity in this study is still in accordance with the life of aquatic organisms, especially phytoplankton, where the corresponding turbidity for the waters is $25 \mathrm{NTU}[10]$.

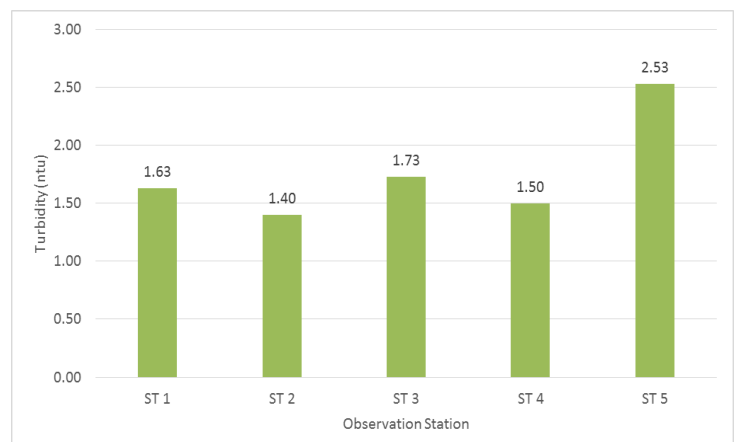

Figure 3. Parameters of turbidity in the waters of lake Teluk Gelam

http://dx.doi.org/10.22135/sje.2021.6.3.84-92 


\subsection{Depth}

Depth is one of the physical paramaters that affects the brightness of the waters, where the deeper the water, the less the intensity of incoming light[11]. The results of the research that has been done obtained that the depth of the waters of Teluk Gelam lake is very varied and still feasible for the life of microorganisms that range from 2.50-5.53 $\mathrm{m}$ [12]. very low water depth levels can result in the intensity of attacks of parasites that have a higher life cycle at the bottom of the water and result in impaired respiratory system and vision for aquatic organisms in case of extreme water receding activity due to sedimentation.

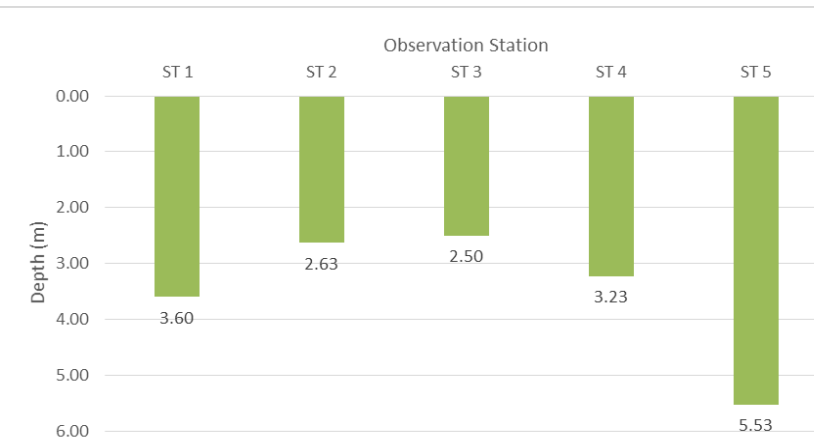

Figure 4. Depth Parameters in the waters of lake Teluk Gelam

\subsection{DO (Disolved Oxygen)}

DO (Disolved Oxygen) is the amount of oxygen dissolved in the waters and the presence of oxygen in the waters is indispensable for the respiration process. In general, the presence of DO in a water is influenced by changes in temperature, where the higher the temperature, the lower the DO content and vice versa. The DO value of the measurement results ranges from $0.39-2.66 \mathrm{mg} / 1$ (Figure 5.). The overall DO value has the highest value of $2.66 \mathrm{mg} / \mathrm{l}$ which is found in station II and the lowest value of $0.39 \mathrm{mg} / 1$ is found in station I. According to[13], the optimal dissolved oxygen value is more than $3 \mathrm{mg} / \mathrm{l}$

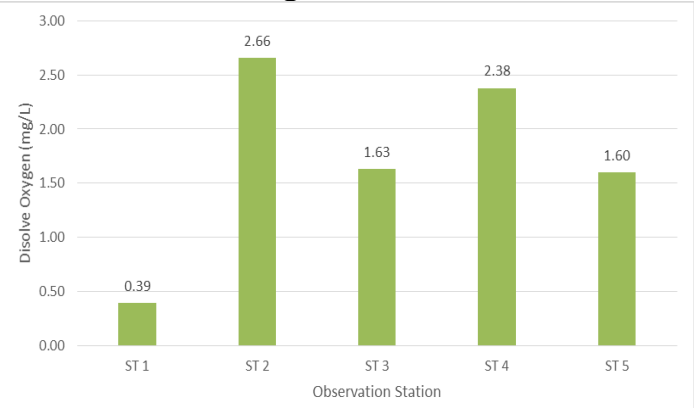

Figure 5. DO (Disolved Oxygen) parameters in the waters of lake Teluk Gelam.
$3.6 \mathrm{pH}$

Based on the results of research that has been done it is known that the value of $\mathrm{pH}$ measurement results in Teluk Gelam lake ranges from 5.41-6.45. It appears that in station II there was an increase in $\mathrm{pH}$ value of 6.45. The increase in $\mathrm{pH}$ value in station II resulted from human activity contamination, the amount of waste or organic and inorganic matter that polluted the waters[14]In a water, the $\mathrm{pH}$ tends to rise in the event of photosynthesis because phytoplankton utilize $\mathrm{CO} 2$ for photosynthesis purposes[15]. In general, the $\mathrm{pH}$ value for optimal phytoplankton growth ranges from 7-8.5[16]. Waters that have a $\mathrm{pH}$ of 6-9 are considered productive because it encourages the dismantling of organic matter in the waters into minerals that can be assimilated by phytoplankton.

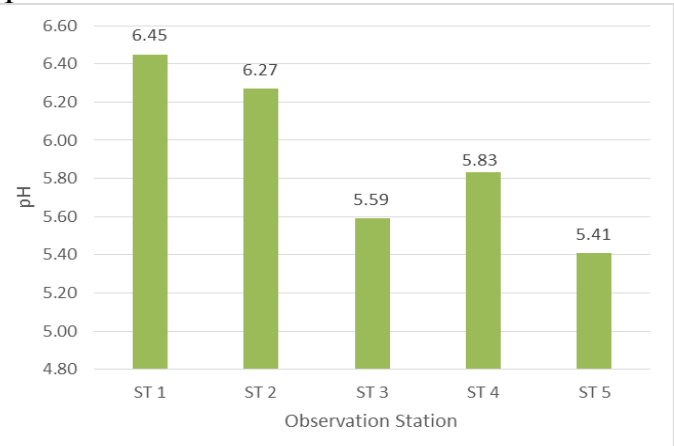

Figure 6. $\mathrm{pH}$ parameters in the waters of Teluk Gelam lake

\subsection{Ammonia}

Ammonia in the water can be derived from organic nitrogen and inorganic nitrogen contained in soil and water derived from the decomposition of organic matter by microbes and fungi. In addition, ammonia is also derived from dentrification in the decomposition of waste by microbes in anaerobic conditions. Ammonia can also come from domestic waste and industrial waste. The results of water quality analysis in Teluk Gelam lake showed that ammonia at each station is still in decent condition, ammonia levels in the waters of Teluk Gelam lake range from $0.001-0.02 \mathrm{mg} / \mathrm{l}$. Based on water quality standards requires a maximum ammonia content of $0.3 \mathrm{mg} / \mathrm{l}$. Thus it can be concluded that the waters of Teluk Gelam lake are included in the condition is still feasible. 


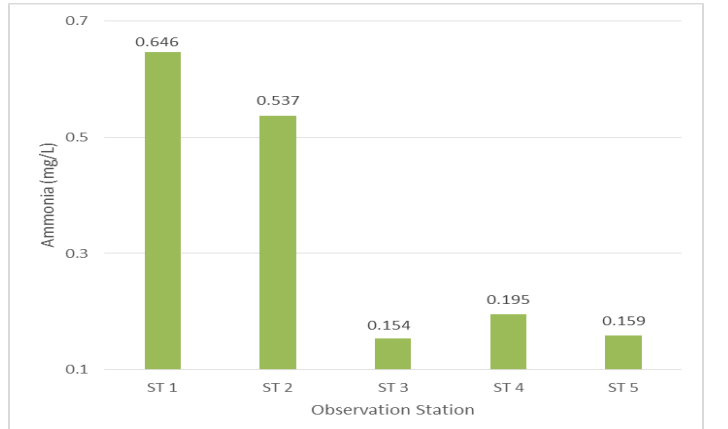

Figure 7. Parameters of Ammonia in the waters of lake Teluk Gelam

\subsection{Nitrate}

Nutriens are indispensable for phytoplankton the grow and reproduce, including nitrogen in the farm of nitrate, well as its role in the protein syinthesis process of animals and plants. The result of nitrate measurements obtained during the study at each station were relatively the same $0,0-0,1 \mathrm{mg} / \mathrm{l}$. In this regard, othe optimal growth of phytoplankton requires nitrate content $0,9-3,5 \mathrm{mg} / 1[17]$. The nitrate leve is in accordance with the quality standard set by kep.51/MENKLH/2004 which is a minimal of 0,008 $\mathrm{mg} / \mathrm{l}$. This shows that nitrate levels have no effect on the abundance of phytoplankton in the waters of lake Teluk Gelam.

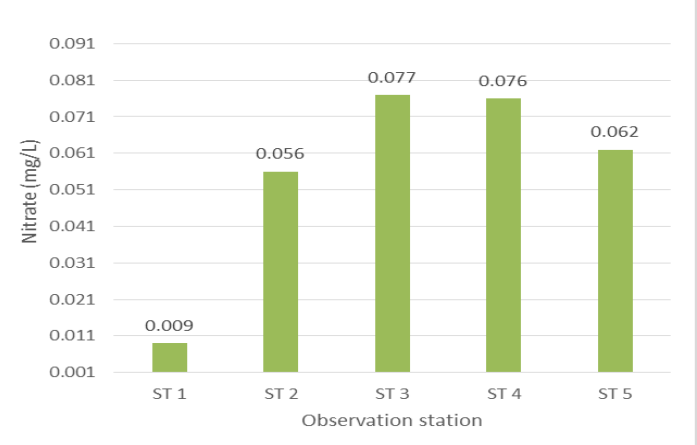

Figure 9. Nitrate parameters in the waters of lake Teluk Gelam

\subsection{Nitrite}

Based on the results of measurement of nitrite levels in the waters of Teluk Gelam lake (Figure 9.) shows the content of nitrites in each station still meets the standard requirements of water contamination quality in accordance with PP No. 82 of 2001 on class III requirements of $<0.06 \mathrm{mg} / \mathrm{l}$. The range of nitrite obtained at each station ranges from $0.005-0.007 \mathrm{mg} /$ $\mathrm{L}$. The range of nitrites obtained at each station ranges from 0.005-0.007 mg/l. The highest nitrite concentration value is found in station II. This is because station II is a residential area and community activities that cause high organic materials derived from human activity activities. The high activity of the community resulted in the large disposal of domestic waste in the form of organic waste and inorganic waste to the body of water. As the domestic waste of organic waste grows, the greater the organic nitrogen and ammonia, which are nitrite-forming components. Too high organic matter content in the waters can lead to eutrophication which will reduce dissolved oxygen levels[18].

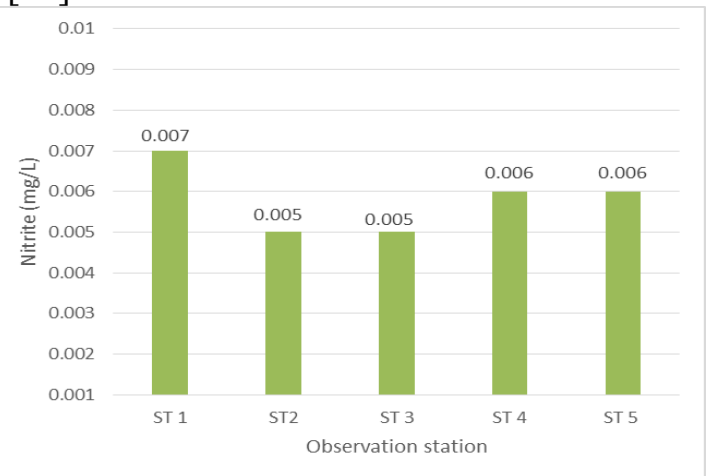

Figure 9. Nitrite parameters in the waters of Teluk Gelam lake.

\subsection{Phosphate}

Phosphate is a nutrient that plays an important role in the productivity of a water. Based on the results of measurements in the waters of Teluk Gelam lake it is known that the phosphate content shows a range of values of $0.047-0.083 \mathrm{mg} / \mathrm{l}$, which is the optimum level. According to[19]. The optimum phosphate levels for phytoplankton growth are $0.09-1.80 \mathrm{mg} / \mathrm{L}$. In a water the presence of phosphate is necessary to meet the nutritional needs of phytoplankton, so that phytoplankton can produce energy. The presence of phosphates can cause excessive in a water can lead to the occurrence of eutrophication (blooming algae).

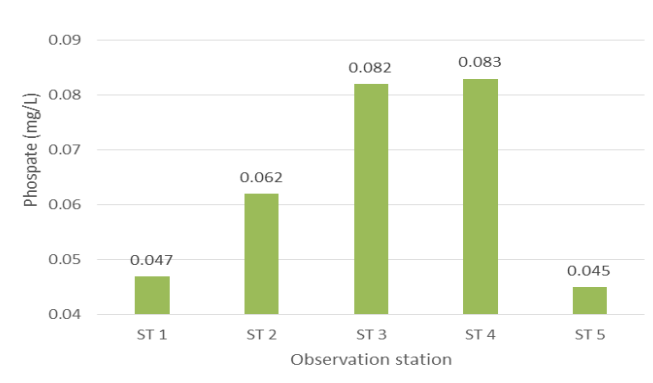

Figure 10. Phosphate parameters in the waters of lake Teluk Gelam

\subsection{Water Quality Evaluation Based on Pollution Index Method}

Based on Government Regulation No. 82 of 2001 explains that the status of water quality is the level of water quality condition that indicates a polluted condition or good at a water source in a certain time compared to water quality standards set by legislation. The results of data analysis from 5 (five) observation stations in Teluk Gelam Lake obtained scores as presented in the table below. 
Table 4. Water Quality of Lake Teluk Gelam District in the Dry Season based on Pollution Index Methods

\begin{tabular}{|c|c|c|c|}
\hline $\begin{array}{l}\text { Station } \\
\text { Observa } \\
\text { sion }\end{array}$ & Area & Total score & Quality status \\
\hline I & $\begin{array}{l}\text { Greenery } \\
\text { Area }\end{array}$ & 0.74 & $\begin{array}{c}\text { Meet the quality } \\
\text { standard }\end{array}$ \\
\hline II & $\begin{array}{l}\text { Residential } \\
\text { area and } \\
\text { community } \\
\text { activities }\end{array}$ & 0.75 & $\begin{array}{c}\text { Meet the quality } \\
\text { standard }\end{array}$ \\
\hline III & $\begin{array}{l}\text { Tourism } \\
\text { Area }\end{array}$ & 0.74 & $\begin{array}{c}\text { Meet the quality } \\
\text { standard }\end{array}$ \\
\hline IV & $\begin{array}{l}\text { Agricultural } \\
\text { and Rice } \\
\text { Fields Area }\end{array}$ & 0.73 & $\begin{array}{c}\text { Meet the quality } \\
\text { standard }\end{array}$ \\
\hline V & $\begin{array}{l}\text { Central area } \\
\text { of Teluk } \\
\text { Gelam Lake }\end{array}$ & 0.72 & $\begin{array}{c}\text { Meet the quality } \\
\text { standard }\end{array}$ \\
\hline
\end{tabular}

Based on the results of calculations by the Pollution Index method can be seen that the quality condition of the waters in the lake Teluk Gelam in 5 (five) stations of the research site still meets the quality standards for phytoplankton communities and fish resources. This is because the pollution index value at each station shows an IP $\leq$ of 1.0. The highest pollution index value is in station II, which is a residential area, this is because the location is a location where there is community activity that causes the influx of organic waste that pollutes the lake waters.

\subsection{Phytoplankton Community Structure}

The abundance of phytoplankton identified during the study were 37 genera from 3 classes, Bacillariophyceae (18 genera), Chlorophyceae (16 genera), and Cyanophyceae (13 genera). The dominant genera were Synedra sp. and Skeletonema.

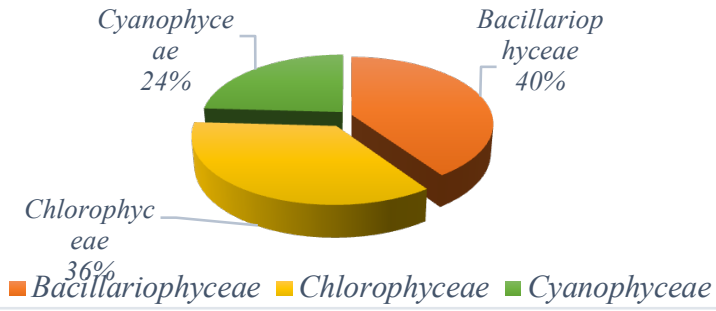

Figure 11. Composition of phytoplankton in Teluk Gelam Lake

The composition of phytoplankton species found during observation was dominated by diatom groups Synedra sp and Skeletonema. This is thought to be because phytoplankton belonging to this class have high adaptation and survival in various aquatic conditions. Following[20] that the large class of diatoms in the waters is due to its ability to adapt to the environment, is cosmopolitan, resistant to extreme conditions and has high reproductive power. [21]it added that the most common species found in the waters caused by human activity were the genus Chaetoceros and Rhizosolenia.

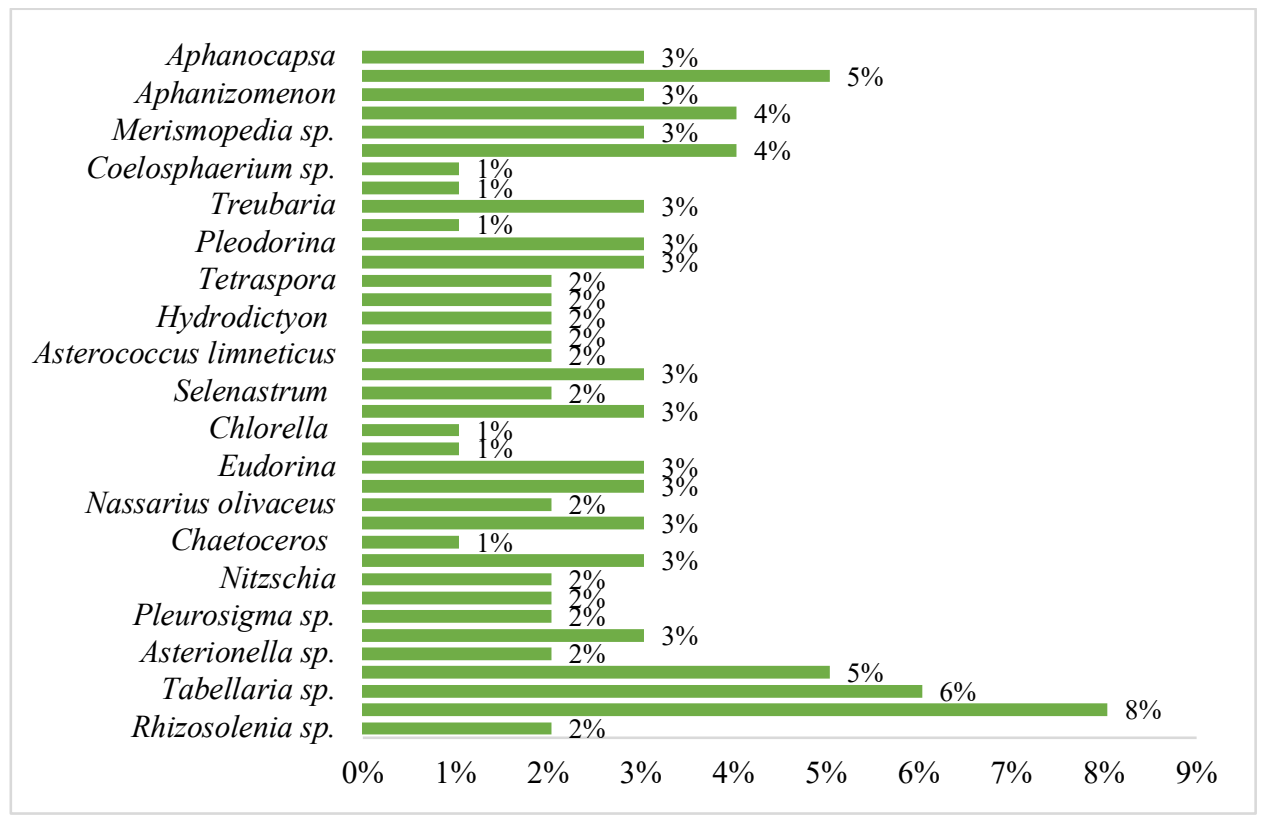

Figure 12. Percentage of phytoplankton in the waters of lake Teluk Gelam

The abundance of phytoplankton in Teluk Gelam Lake was 900-7650 cells / m3. The highest phytoplankton abundance was found at station 1 of 7650 cells $/ \mathrm{m} 3$, and the smallest was found at station 3 , with 900 cells $/ \mathrm{m} 3$ abundance. The factors that affected the abundance of phytoplankton are sunlight, temperature, sun, salinity, competition, speed of growth, and the process of predatory. According to[22], the phytoplankton abundance in the range of $0-2000$ individuals $/ \mathrm{L}$ is categorized as oligotrophic, mesotrophic are the moderately productive waters with 2000-15000 individuals/L abundance, while Eutrophic is the highly productive waters with more than 15000 individuals/L 
abundance.

Based on the results of research that has been carried out, the most common types of fish catch are snakehead fish by $47 \%$, then sepat fish as much as $27 \%$, seluang fish $13 \%$, lais fish $5 \%$, toman fish and tambakan as much as $4 \%$. This is because snakehead fish are biologically able to withstand acidic water environments such as swamps. Teluk Gelam lake is a lake water and is located in a swamp forest environment (rawa lebak). According to[23], in a condition of lack of water, the snakehead fish is still able to survive because the snakehead fish has a breathing apparatus so that it can utilize the free oxygen in the air for its breathing process.

\section{Conclusion}

The water quality of Teluk Gelam Lake was in adequate condition for the organism's life, especially phytoplankton. There were three classes of phytoplankton identified, i.e., Bacillariophyceae, Chlorophyceae, and Cyanophyceae, with various genera. The lake was categorized as mesotrophic (moderately productive). he most common types of fish catch are snakehead fish by $47 \%$.

\section{References}

[1] O. H. A. G.Flock., Lake and Reservoir Guidance Manual. 1990.

[2] Yuliana, "Struktur komunitas dan kelimpahan fitoplankton dalam kaitannya dengan parameter fisika-kimia perairan di danau laguna ternate, maluku utara. Struktur komunitas dan kelimpahan fitoplankton. 4 (1).," J. Protein., vol. 14, no. 1, pp. 85-92, 2007.

[3] Sagala P Effendi, "Komposisi dan Keanekaragaman Benthos dalam menilai Kualitas Air Sungai Lematang, di Desa Tanjung Muning, Kecamatan Gunung Megang Kabupaten Muara Enim.," J. Penelit. Sains, vol. 15, no. 2 (D), 2012.

[4] Erlania, "Pengendalian Limbah Budidaya Perikanan Melalui Pemanfaatan Tumbuhan Air dengan Sistem Constructed Wetland.," $J$. Media Akuakultur, vol. 5, no. 2, 2010.

[5] S. Syawal, M. S., Wardiatno, Y. \& Hariyadi, "Pengaruh Aktivitas Antropogenik Terhadap Kualitas Air, Sedimen dan Moluska di Danau Maninjau, Sumatera Barat.," J. Biol. Trop., vol. 16, no. 14, 2016.

[6] I. Harianto, E. \& Efendi, "Analisis Fisika Kimia Perairan untuk Pemilihan Lokasi Budidaya Ikan Kerapu (Serranidae) di Teluk Saleh Kabupaten Sumbawa, Nusa Tenggara Barat Dengan Metode Storet Dan Analisis

Vol. 6 No. 3, 84-92
Multivariat.," J. Akuakultur Sungai dan Danau, vol. 2, no. 18, 2017.

[7] Menteri Lingkungan Hidup Republik Indonesia, "Keputusan Menteri Lingkungan Hidup Nomor; 115 Tahun 2003 Tentang Pedoman Penentuan Status Mutu Air," Jakarta, 2003.

[8] H. \& S. Gayosia, A. P., Basri, "Kualitas Air Akibat Aktivitas Penduduk di Daerah Tangkapan Air Danau. Kabupaten Aceh.," J. Manaj. Sumberd. Lahan, vol. 4, no. 13, 2015.

[9] dkk Faturohman, Isni, "Korelasi Kelimpahan Plankton dengan Suhu Perairan Laut di Sekitar PLTU Cirebon.," J. Perikan. Kelautan., vol. 7, no. 1, pp. 115-122, 2016.

[10] I. dan A. Arlindia, "Analisis Pencemaran Danau Maninjau dari Nilai TDS dan Konduktivitas Listrik.," J. Fis. Unand, vol. 4, no. 7, 2015.

[11] S. N. J. Tokah, C., Undap, S. L. \& Longdong, "Kajian Kualitas Air Pada Area Budidaya Kurungan Jaring Tancap (KJT) di Danau Tutud Desa Tombatu Tiga Kecamatan Tombatu Kabupaten Minahasa Tenggara.," $J$. Budid. Perair., vol. 5, no. 11, 2017.

[12] T. A. Barus, Pengantar Limnologi; Studi Tentang Ekosistem Air Daratan. Medan: Press, 2004.

[13] M. C. Mainassy, "Pengaruh Parameter Fisika dan Kimia terhadap Kehadiran Ikan Lompa (Thryssa baelama Forsskal) di Perairan Pantai Apui Kabupaten Maluku Tengah.," $J$. Perikan. Univ. Gadjah Mada, vol. 2, no. 19, 2017.

[14] H. Effendi, Telaah Kualitas Air Bagi Pengelolaan Sumberdaya Alam, \& Lingkungan Perairan., Cetakan Ke. Kanisius, 2003.

[15] Alaert dan Santika, Metoda Penelitian Air. Usaha Nasional. Surabaya, 1984.

[16] W. Muhaemi, Tuhumury, R. \& Siegers, "Kesesuaian Kualitas Air Keramba Ikan Nila (Oreochromis niloticus) di Danau Sentani Distrik Sentani Timur Kabupaten Jayapura Provinsi Papua.," J. Fish. Dev., vol. 1, no. 14, 2015.

[17] Mackenthum KM, The Practice Of Water Pollution Biology, United States Departement in Interior, Federal Water Pollution Control Administration. Devision of Technical Support, 1969.

[18] A. R. Simbolon, "Pencemaran Bahan Organik dan Eutrofikasi di Perairan Cituis, Pesisir Tangerang.," J. Pro-Life, vol. 3, no. 2, 2016.

[19] K. P. Malaha, "Tingkat Kesuburan Perairan Berdasarkan Kandungan Unsur Hara Nitrat (N) Dan Phosfat (P) Di Perairan Sungai Belendete Kabupaten Kolaka.," J. Visi, vol. 
17, no. 3, pp. 299-310, 2004.

[20] dan E. F. Dewanti, L.P.H., I.D.N.N. Putra, "Hubungan Kelimpahan dan Keanekaragaman Fitoplankton Dengan Kelimpahan Dan Keanekaragaman Zooplankton di Perairan Pulau Serangan. Bali.," J. Mar. Aquat. Sci., vol. 4, no. 3, p. 324.335., 2018.

[21] Isnaini, "Struktur Komunitas Fitoplankton di Perairan Muara Sungai Banyuasin Sumatera Selatan.," Maspari Journal., vol. 4, no. 1.
2014.

[22] Sutomo, "Stuktur Komunitas Fitoplankton di Perairan Teluk Sekotong dan Teluk Kodek, Kabupaten Lombok.," J. Ilmu dan Teknol. Kelaut. Trop., vol. 5, no. 1, pp. 131-144, 2013.

[23] Muslim., "Teknologi Pembenihan Ikan Gabus (Channa Striata).," J. Ruaya, vol. 7, no. 2, 2019. 